\title{
The Use of Econometric Analysis for Interest Rate Risk, the Impact of GDP and Inflation Factor in Deposit Interest (the Case of Albania)
}

\author{
Prof.Asoc. Ina Pagria \\ Prof.Asoc. Dori Risilia
}

Prof.Asoc. Maksim Meço

Prof.Asoc. Skënder Uku

PHD. Albana Gjoni

Faculty of Economy and Agribusiness, Agricultural University of Tirana, Tiranë, Albania

\section{Doi:10.5901/ajis.2016.v5n3s1p177}

\section{Abstract}

The risk, is an economic concept that gives the impression of a negative impact, unexpected event, condition upon which we can not influence. But it is important to distinguish between risk and danger as both are possible events in the future, but with different effects in conditions that can be affected. Not only the individual economic life, bot also businesses have faced different financial and business risks and its analysis is study object for many commercial units. Exposure to risk has affected in a way that many businesses and financial institutions should take the appropriate measures to protect against this exposure through the use of needed techniques for running it. Banks use different techniques in the management of risk, especially the risk of interest rates and that most used is funds GAP, as a technique, the size of which indicates the risk that bank the bear from changing interest rates and that is reflected in the net interest income. Which are the causes of this interest rate risk? Banks play a vital role in economic growth and in countries development, mainly through diversification of risk for themselves and other economic agents. Interest rate risk is one of the most important financial risks that bank faces. Interest rate risk is the possibility that changes in interest rates affect the interest income and the market value of assets of any investor. A large part of the income derived from net interest income, which comes as the difference between some asset items with the balance sheet liability items of the bank. Fluctuations in interest rates affect the interest rate and the value of the bank, making the management of interest rate risk to be vital to the success of a bank. Based on some basic concepts of risk theory, such as the target in terms of risk, event risk, the probability attached as well as the impact of event risk target, our paper aims to review the risk of interest rates as well as its main direction methods. Special attention was given in this paper to factors that influence the interest rate on deposits as well as assessing the impact of these factors on interest rate, by using an econometric model. The goal is the study of the dependence of the interest rate on deposits from GDP and the inflation rate. For the realization of this paper we have used the program Eviews through which it is established and is proven main hypotheses: if you change the level of GDP, exchange rates ALL / EUR and the rate of inflation, then the level of interest rates on deposits will be adapt to this change. Expressed in other words, the level of deposit interest rates, is depending on GDP, exchange rates ALL / EUR and the rate of inflation.

Keywords: risk, interest rate, deposite, econometric analysis

\section{Introduction}

Interest rates constitute one of the most important channels of monetary policy transmission. The functioning of the transmission channel depends on macroeconomic conditions and financial structures of the country. Entering the currency physical euro and the replacement or the close relationship of the national currency of some countries in the region with the euro is strengthening more the tendency for integration in the region and the European Union, the trade development by enabling strong links in the level of interest rates in these countries. As it knowns interest rates, are constantly changing. They are depending on the conditions of the monetary and the financial market, who themselves are depended by all economic activity of the, the intervention of the monetary and financial in authorities money and capital markets, as well as changing conditions in the international financial and monetary markets. The risk that comes from changing the interest rate includes at the same time the bank's income as well as the economic value of its assets, 
resources and items out of balance sheet.

Otherwise we can say that is the risk of lower earnings due to movements in interest rates. Interest rates have the power to influence people's lives: how willing are people to save and how much interest have businesses to invest. Affecting cconomic decisions that different people undertake, they serve as a determining factor for investment in the overall level of the economy. When interest rates decline, investment will increase as a result of lowering the borrowing cost. In this case, people rush to buy a house, a car, and in this way they feel more optimistic about the future. To understand the economic forces that affect the volatility of interest rates, we should first give a definition of them. The interest rate is a price, and like any other price it relates to an exchange or transfer of a commodity or service between a buyer and a seller. This special type of exchange is a credit or loan which includes a lender and a borrower.

Borrower has the advantage of immedialtely usage of the received funds, while the lender submits these funds by being temporarily removed their use. Because these lender sacrifice immediate use of the funds, they require an additional compensation above the money borrowed amount. This fee is called interest or otherwise, the price that a borrower pays for the utilization of funds to lenders. Expressed simply, the interest rates are the price of borrowing. This paper applies to a better understanding of the problem related to the interest rate. Referring to the above is understandable that even in the case of the banking sector in Albania are doing studies to high light the issues linked with the interest rates risk by various macro factors, which contribute to a better clarification and addressing of this topic. From this problem we can arise and test many hypothesis. The new focus that this paper address is the econometric problem by drawing the appropriate conclusions and recommendations.

\section{Objectives}

The objective of the paper is to create a better understanding of the problems related to the interest rate in the banking system in Albania and also to analyses the factors that affect interest rate.

\section{Methods}

\subsection{The lending activity of the banking system 2015-2016}

Outstanding loans of the banking sector has increased during the first half of the year supported by the expansion of credit to businesses in local currency. The process of clearing balances of loan loss has continued, but with slower rythyms than in 2015. At the end of the period, the first half of the loan balance stood at 597.4 billion, were $2 \%$ higher compared to the end of 2015. During the period, are deleted from the banks balance sheets 5.9 billion leke -loans classified as "loss". If the lost loan would not have been deleted, the increase in outstanding loans during the period would be $3 \%$. In annual terms, driven by the process of deleting the lost loans, outstanding loans marks a contraction of $0.3 \%$ at the end of the period. Corrected value for the deleted loans, the annual growth of outstanding loans were 3.1\%. Due to the considerable weight of foreign currency loans, the performance of the lek exchange rate affects the nominal value of loans reported in local currency. To calculate the surplus at the end of June 2016, the performance of the exchange rate has impacted negatively in the reported value of the loan, mainly due to the depreciation of the euro against the local currency. Excluding this effect, the balance of the loan period would be extended by $2.3 \%$.

The downward trend of interest rates on the loan, especially for ALL has supported the performance of the new loan. In June 2016, the weighted average interest rates on new whole, marked 6:42\%, unchanged from the December 2015 level reflecting the reduction in base rate, the weighted average rate in domestic credit score $7.3 \%$, down $0.4 \%$ during the period. The interest rate on new loans in euros and US dollars, marked respectively $5.3 \%$ and $5.5 \%$.

According to the sectors, the main contribution to the progress of new loans during the period, was given by business sector. In fact, during the period, the business benefited $79 \%$ of new loans, while individuals about $21 \%$. The new credit to the business sector has narrowed by $12.6 \%$, mainly due to the contraction of "overdraft" credit, which occupies the major share in new business loans (about 50\%). Meanwhile, in annual terms, new credit to businesses grew slightly by $0.5 \%$, driven by significant growth with $48 \%$ of new loans for "investments in equipment purchases," which accounts about $19 \%$ of the total. The new credit to households has shown also positive performance during the period, compared with a year ago. By currency maturity, the main contribution to the performance of the loan period was given by credit in Lek for the long and medium term. The new credit in Lek occupies $52 \%$ of the total and continues the upward trend of recent years, increasing by $14.3 \%$ during the period. In terms of maturity, new short credit represents $54 \%$ of the total (decreased by 3.4 percentage points during the period), medium-term accounts for $17 \%$ of the total (increased by 
$2.3 \mathrm{pp}$ over the period) and long occupies $28 \%$ of the total (increased by $1.1 \mathrm{pp}$ over the period).

\subsection{Depository activity of the banking system 2015-2016}

In the first half of the year, the deposits value was approximately 1,100 billion, was virtually the same as the end of 2015, but about $2 \%$ higher compared to a year ago. The average annual growth rate of deposits has slowed significantly and stays down the long-term average. The deposits structure and the annual growth rate continues to be dominated by foreign currency deposits, which grew by an average of $5.4 \%$. The decline in interest rates was accompanied by shrinkage of deposits and significant increase in weight and level accounts.

Foreign currency deposits have strengthened contribution to the growth of deposits in the banking sector. During the period, average annual growth in foreign currency deposits recorded $5.4 \%$, while deposits in domestic currency fell by $0.4 \%$. As a result, at the end of the period, foreign currency deposits represented $52 \%$ of total deposits. If the value of foreign currency deposits exclude the effect of changes in exchange rates, annual growth in foreign currency deposits at the end of June 2016 would be $5.9 \%$, while the total deposits $2.4 \%$. Viability of deposits in the period, contributed to the growth of deposits of households and business deposits decline.

Household deposits, which account about $85 \%$ of banking sector deposits, increased $1.5 \%$ on average during the first half, going down the annual average 33 of three years (2.6\%). Business deposits recorded a decrease of $4.5 \%$ from their level in December 2015, although remain above $8.6 \%$ of their value with a year ago. Compared with a year ago, between individual's deposits in domestic and foreign currency, and businesses in domestic and foreign currency, the fastest growth was marked by business deposits in foreign currency, while individual deposits in ALL marked the big decline. At the end of the period, foreign currency deposits account about $50 \%$ of individual deposits and about $63 \%$ of the business deposit. Current accounts and deposits have different contribution to the performance of the deposits value. The value of current accounts near to the banking sector rose further during the period being in the end of its approximately $31.2 \%$ higher than a year ago. On the other hand, deposits fell in value during the period, both in weight (of total deposits), while they prevail in deposits value of banking sector.

Compared with the end of the year, deposits fell by 22.7 billion or $3.2 \%$, and their share went down to $63 \%$ of total deposits. According to business size, deposits have been increased for the group of medium banks, but have declined to groups of large and small banks. For large banks, deposits have fallen by $1 \%$, but these banks manage $69 \%$ of the deposit sector. Movements of deposits for the group of medium banks (increased by $11 \%$ ) and the group of small banks (decreased by $25 \%$ ) are caused mainly by the reclassification of a bank by small-sized bank.

During the period, the banking sector has had a new influx of new term deposits (new resettlement and placement) to about 274.7 billion. Within the structure of deposits, there is a slight shift towards longer maturities. According to currency, the influx of new deposits in domestic currency fell by $21.5 \%$, in US dollar it fell by $35 \%$, while the euro it rose by about $6 \%$. During the period, the average interest rates on new deposits in Lek-term downward trend has continued, scoring $0,14 \%$, while for major currencies have been around $0.1 \%$

\section{Econometric Analysis}

In our paper we aim to analyze the interest rate risk for the banking system. The undertaken way in this case has been in the construction of econometric models and their regression analysis. "Econometric Model is a theory, a hypothesis or a set of hypotheses by which are analyzed the economic phenomena and can be predictions with them." Secondary data were obtained from sources such as the Bank of Albania's Institute of Statistics, Ministry of Finance. The data are in the form of time series, get to Albania from 2001 to 2015. Time series used must be such as to fit to the data series indicators of interest rate represent a form quite suitable for econometric analysis, especially in conditions where the available data pertaining to the full period. Regarding other macroeconomic factors or on the assets and liabilities structure of banks are seeking different data sources with the aim of gathering accurate information in the form of time series published, so that the latter can be used for regression model. Consequently multifactorial regression model was applied only to an annual time series which appear official and public information to the Bank of Albania and the Institute of Statistics (INSTAT). Processing of data and hypotheses testing is made by econometric program called eviews.

Construction of the economic models is based on the pursuit of some econometric analysis steps.

1) Formulation of models and hypotheses or economic theory.

In our focus is the risk of interest rates based on the assumption that basic interest rate in accordance with a specified period "t" depends on factors such as: gross Domestic Product GDP, the rate of interest on loans, 
deposit interest rate, inflation, exchange rate ALL / EUR. Our assumption is made on the basis of the theory that all these factors affect the risk of interest rates and analytically we have proved that this hypothesis is true (by building models).

2) Afeter having settled on economic theory, we have speciefiedc the mathematical models suitable for ideal economic models that are formulated above.Considering that in our theory we were based on interest rates, then the most appropriate model for this theory is linear regression model.

$Y=C_{(1)+} C_{(2)}{ }^{*} X_{1}+C_{(3)}{ }^{*} X_{2}+C_{(4)} * X_{3}+C_{(5)}{ }^{*} X_{4}+C_{(6)}{ }^{*} X_{5}$

$\mathrm{I}=\mathrm{C}_{(1)}+\mathrm{C}_{(2)}{ }^{*} \mathrm{GDP}+\mathrm{C}_{(3)}{ }^{*} \mathrm{I}_{\mathrm{K}}+\mathrm{C}_{(4)}{ }^{*} \mathrm{I}_{\mathrm{D}}+\left.\mathrm{C}_{(5)}{ }^{*}\right|_{N}+\mathrm{C}_{(6)}{ }^{*} \mathrm{~K}_{\mathrm{K}}$

Where:

I=Base interest rate

$\mathrm{GDP}=$ Increase of gross domestic product $\mathrm{l}_{\mathrm{k}}=$ Credit interest rate

ID=Deposit interest rate

IN=Inflation

$\mathrm{K}_{\mathrm{k}}=$ Exchange rate All/euro

The dependent variable is the base rate measured by new disbursements on an annual basis, disbursed by the Bank of Albania for the period 2001-2015.

Identification of risk factors in determining the interest rate:

Considering that the interest rate risk for the Albanian banking system is due to the volatility of the basic interest rate, then the analysis of the factors affecting this indicator meets the first step of the process mentioned above. Following this issue are identified and analyzed the determinants that affect the level of interest rate risk for the banking system. In this issue the treatment is limited to theoretical aspects and analysis of the cause-effect link of the determinants identified factors. In other words is represented an econometric analysis of macroeconomic factors.

Basic interest rate, also known as the price of keeping the money, is the rate settled by the Bank of Albania to keep inflation within the target band. This rate plays the main instrument, used to transmit monetary policy signals in the economy. The base interest rate is applied by the Bank of Albania in the weekly auctions of repurchase agreements (repo) and reverse repurchase agreements (reverse repo-t). Currently, in our country the key interest rate is at 1.25\%. T repo and reverse repo-t are instruments used by the Bank of Albania to manage the liquidity of the banking system. The base interest rate serves as a guideline for the level of interest rates in the economy. This rate determines the rate of interest on deposits and loans of the Bank of Albania overnight. Also, it affects the interest rate on the interbank market, Lek deposits at commercial banks and treasury bills, and credit extended in domestic economy.

a. Economic growth

It is considered as the main indicator of the welfare level in economy. This indicator shows whether the economy is growing or falling. It is the basic indicator of a country which affects the majority of other macroeconomic indicators. The impact of this factor in the interest rate indicator is undisputed because of its impact on various factors, especially in:

- Economic growth affects the level of individuals and businesses welfare which is forwarded to the request for new investment or about their investment behavior.

- Economic growth affects the perception of domestic and foreign investors who forwarded it to the level of investment in the country, money circulation.

This concept is measured by the GDP variable which appears as an independent variable expressed as a percentage, from the perspective of the sign or the impact type is expected to have a negative correlation with the rate of interest, since affects the welfare of the country.

b. Loans interest rate

Independent variable which directly affects the volatility of the interest rates, is the main determinant of this indicator. It influences when the movements in market interest rates on borrowing and lending are not align perfectly, creating the revenue risk. It is expected to have a positive relationship with the base interest rate.

c. Deposits interest rate

Independent variable affects directly in key interest rates, also as loans rates even this norm exert an influence on the income risk that is the interest rates risk element, is expected to have a positive relationship with the basic interest rate, ie how much volatile this rate, more variable is the basic rate and consequently is increase the risk level.

d. Inflation rate

A durable inflation maintains the balances within the economy but a high inflation intends the decrease of the 
money purchasing power of and its devaluation. Well, it would cause the risk of inconsistency between the magnitude of the change in asset and liabilities prices. Independent variable, is expected to have a positive correlation with the interest rates, as normality the inflation increase is associated with interest rate rising $\mathrm{s}$.

e. Exchange rate

The volatility of the exchange rate, particularly in economies where foreign currencies are used not only in foreign trade but also for domestic transactions, affects the basic interest rate in two perspectives: first fluctuation of the exchange rate affects the competitiveness of the economy towards foreign trade partners, which affects the level of import-export, through impact of exchange rate risk.

It is expected to have a negative correlation with the interest rate, an increase of the exchange rate will mean local currency devaluation and consequently leads to interest rates increase to compensate the losses.

\subsection{Raised hypotheses}

To achieve the objectives and the beginning of econometric analysis first is important to make the establishment of hypotheses that should be tested. Raised hypotheses related with the interest rate risk in the banking sector in Albania are as follows:

H0: GDP interest rate for the loan, the interest rates for deposits, inflation and exchange rate are not important factors in the basic interest rates in the Albanian banking sector.

H1: GDP, interest rate for the loan, the interest rates for deposits, inflation and exchange rate are important factors in the basic interest rates in the Albanian banking sector.

\section{Results and Discussion}

The purpose of this paper is to highlight the importance of factors affecting the volatility of interest rates in Albania, consequently, this reflects the impact or the existence of interest rate risk. This constitutes the main hypothesis of this paper. The scale of the problem formulation is not high, although it would rely on appropriate theoretical approach to justify the links between concepts, we have not identified any Albanian author refer to this issue. The method that we judge as the most appropriate for achieving the goal is the econometric modeling, and we will use a multi-linear regression model. The model evaluatin will be through the Eviews programme.

\section{$\mathrm{I}=41.5-1.9 * \mathrm{GDP}+1.5{ }^{*} \mathrm{~N}_{\mathrm{K}}+0.47{ }^{*} \mathrm{~N}_{\mathrm{D}}+0.45 *{ }_{\mathrm{N}}-0.3 * \mathrm{~K} \cdot \mathrm{K}$}

Table. 1: Econometric model

\section{Dependent Variable: INTERES}

Method: Least Squares

Date: 30/10/16 Time: 05:13

Sample: 111

Included observations: 11

INTERES $=\mathrm{C}(1)+\mathrm{C}(2){ }^{*} \mathrm{GDP}+\mathrm{C}(3) *$ INTKREDIE+C(4)*INTDEPOZITAVE+C(5)*INFLACION+C(6)KURS

\begin{tabular}{|c|c|c|c|c|}
\hline & Coefficient & Std. Error & t-Statistic & Prob. \\
\hline $\mathrm{C}(1)$ & 41.56877 & 30.42112 & 1.366445 & 0.2300 \\
\hline$C(2)$ & -1.917779 & 0.812503 & -2.360333 & 0.0347 \\
\hline$C(3)$ & 1.509591 & 0.685994 & 2.200590 & 0.0190 \\
\hline$C(4)$ & 0.476457 & 0.856624 & 0.556203 & 0.6020 \\
\hline$C(5)$ & 0.455005 & 0.971729 & 0.468243 & 0.6593 \\
\hline$C(6)$ & -0.358120 & 0.205944 & -1.738921 & 0.0425 \\
\hline R-squared & 0.771676 & Mean dependent var & & 9.081818 \\
\hline Adjusted R-squared & 0.543351 & S.D. dependent var & & 1.756598 \\
\hline S.E. of regression & 1.187035 & Akaike info criterion & & 3.483245 \\
\hline Sum squared resid & 7.045257 & Schwarz criterion & & 3.700279 \\
\hline Log likelihood & -13.15785 & F-statistic & & 3.379736 \\
\hline Durbin-Watson stat & 1.912791 & Prob(F-statistic) & & 0.003739 \\
\hline
\end{tabular}

Before we do the analysis of the results we see that fot the validity coefficients, the coefficients of the regression C2, C3, C6, respectively at factors GDP, rate it nteresit credit, exchange rates with 95\% certainty are statistically significant 
because they have probabilities less than 0.05 .

While coefficients $\mathrm{C4}$, C5 near factors at the deposit interest rate, inflation, resulting insignificant because they have probabilities greater than 0.05 per $95 \%$ certainty. Consequently, we can say that the whole model is not important therefore ia not considered a good model for analyzing the factors. For this we try a new model by eliminating insignificant coefficients.

H0: (Coefficients C2, C3, C4, C5, C6) are not important

H1: (Coefficients C2, C3, C4, C5, C6) are important

The best econometric model:

\section{$\mathrm{I}=24.7-1.4^{*} \mathrm{GDP}+1.7^{*} \mathrm{~N}_{\mathrm{K}}-0.2^{*} \mathrm{~K}_{\mathrm{K}}$}

Table 2.

Dependent Variable: INTERES

Method: Least Squares

Date: 30/10/16 Time: 22:00

Sample: 111

Included observations: 11

INTERES $=C(1)+C(2) *$ RRITJEGDP+C(3)*NORMEKREDI+C(4)*KURSKEMBIMI

\begin{tabular}{|c|c|c|c|c|}
\hline & Coefficient & Std. Error & t-Statistic & Prob. \\
\hline $\begin{array}{l}C(1) \\
C(2) \\
C(3) \\
C(4)\end{array}$ & $\begin{array}{c}24.73273 \\
-1.453669 \\
1.748760 \\
-0.237295\end{array}$ & $\begin{array}{l}17.48883 \\
0.427889 \\
0.485813 \\
0.108104\end{array}$ & $\begin{array}{c}1.414202 \\
-3.397305 \\
3.599654 \\
-2.195058\end{array}$ & $\begin{array}{l}0.2002 \\
0.0115 \\
0.0087 \\
0.0642\end{array}$ \\
\hline $\begin{array}{l}\text { R-squared } \\
\text { Adjusted R-squared } \\
\text { S.E. of regression } \\
\text { Sum squared resid } \\
\text { Log likelihood } \\
\text { Durbin-Watson stat }\end{array}$ & $\begin{array}{c}0.877418 \\
0.793169 \\
1.055175 \\
7.793764 \\
-13.71318 \\
1.596333 \\
\end{array}$ & $\begin{array}{l}\text { Mean dependent var } \\
\text { S.D. dependent var } \\
\text { Akaike info criterion } \\
\text { Schwarz criterion } \\
\text { F-statistic } \\
\text { Prob(F-statistic) }\end{array}$ & & $\begin{array}{l}9.081818 \\
1.756598 \\
3.220578 \\
3.365268 \\
6.904589 \\
0.006896\end{array}$ \\
\hline
\end{tabular}

\subsection{Results interpretation}

$\mathrm{C}_{1}=24.73$ is the term free, and it has no economic significance.

$\mathrm{C}_{2}=(-1.4)$ is partial regression coefficient of GDP factor, if GDP increases by $1 \%$ interest rate is expected to be reduced by $1.4 \%$, if other factors remain unchanged.

$C_{3}=1.7$ it shows if the loan interest rate increases by $1 \%$, the interest rate is expected to rise by $1.7 \%$ if other factors remain unchanged.

$\mathrm{C}_{4}=(-0.2$ it indicates whether the exchange rate ALL / Euro increased by 1 unit is expected to lower interest rates by $0.23 \%$ if other factors remain unchanged.

$\mathrm{R}^{2}=87 \%$ is the determination coefficient, ie $87 \%$ of the total variation of the interest rate is determined by the variation in GDP growth, interest rates on loans and exchange rate.

\subsection{Hypothesis on partial regression coefficients}

HO: (Coefficients C2, C3, C4 are not important)

H1: (Coefficients C2, C3, C4 areimportant)

For the regression coefficient C2 GDP factor we conclude that is statistically important with $95 \%$ certainty because it has the probability less than 0.05 ( $5 \%$ level of uncertainty).

For the regression coefficient C3 as interest rate loan factor with 95\% security we conclude that is statistically important because it has the probability less than 0.05 ( $5 \%$ level of uncertainty) Whereas for the regression coefficient C4 we conclude $90 \%$ is statistically significant because it has the probability less than 0.1 ( $10 \%$ uncertainty level).

In addition to above tests it is also important the model testing in general, so the influence of independent factors on the dependent variable. In other words it is important to test whether the chosen model describes correctly or sufficiently the connection between the involved variables. When from coefficients estimation of partial regression results 
that they are all important, it has no doubt that their influence so the model would appear important, but if some of the independent variables result important and some others not important, it is not clerar if their joint impact is significant or not.

H0: The raised model is not statistically significant (coefficients are all equal to zero, $\mathrm{Ci}=0$ for every $\mathrm{i}=1,2,3 \ldots \mathrm{n}$ )

The raised model is statistically significant (coefficients are all equal to zero, $\mathrm{Ci}=0$ for every $\mathrm{i}=1,2,3 \ldots \mathrm{n}$ )

With $95 \%$ certainty we can say that the whole model is statistically significant because the probability (F-statistic) = 0.00689 is less than 0.05 (level of uncertainty) .Even after performing other tests on the model validity (test of normality, heteroskedasticitetit, autocorrelation), it appears a good model.

\section{Conclusion and Recommandations}

- Banks should clearly define the individuals and / or responsible committees for managing the risk of interest rate and ensure that there is appropriate segregation of duties in key elements of the management risk process to avoid potential interest conflicts.

- Banks should establish and enforce limitations and practices that maintain exposures to interest rate risk at levels that consistent with their internal policies.

- Interest rate risk will be materialize in the case of an interest rate increase, which, due to the negative gap will soon affects the bank costs activity, compared with its earnings.

- This risk has also a indirectly component related to the negative effect of increasing the interest rate to borrowers who have a loan with a variable interest rate. Even in this case, it is necessary for banks to assess quantitatively the impact of adverse scenarios and act to reduce exposure.

- Consistently fall of interest rates is accompanied by contraction of deposits and significant increase in weight and accounts level.

- An accurate and in time management information system, it is essential to manage the risk exposure to interest rates, and to inform the management and to support compliance with internal policies approved.

- The results of the analysis E-views express a negative correlation between GDP growth and the basic interest rate, economic growth affects in lower interest rate.

- There is a positive correlation between loan interest rate and the basic interest rate, it represents the highest impact of this rate.

- There is a negative correlation between the exchange rate and interest rate if the exchange ALL / EUR increased by one unit, this leads to devaluation of the national currency (ALL), and as a result will increase interest rates in order to compensate the loss from impairment.

- Factors that have influence with high volatility in interest rates are the interest rates of loans and GDP growth.

\section{References}

Banka e Shqiperise. (2015). Raporti i mbikeqyrjes financiare 2015. Tirane.

Banka e Shqiperise. (2015). Raporti Vjetor 2015. Tirane.

Banka e Shqipersise. (2016). Raporti i stabilitetit financiar. Tirane.

Cakrani E, 2014, kursi reali kembimit dhe ndikimi i tij ne ekonomi, rasti i Shqiperise.

Edwards, A, (1989), Real Exchange Rates Devaluation and Adjustment. Cambridge, Mass. Mit Press.

Vika I, Tanku A, Gjermeni M, (2007). Roli i kursit te Kembimit ne shenjestrimin e inflacuinit,

si veprohet?

Banka e Shqipërisë. (2000). Udhezim mbi administrimin e riskut te normës se interesit", Miratuar me vendim të Këshillit Mbikëqyrës të Bankës së Shqipërisë.

Ministria e Financave. (2015, Janar). www.minfin.gov.al. Retrieved from www.google.com: http://www.financa.gov.al/files/userfiles /Programimi_EkonomikoFiskal/Programi_Ekonomik_e_Fiskal/Programi_Ekonomik_e_Fiskal_2014.pdf 


\section{Appendix}

Heteroskedasticity test (test White)

A regression analysis is that the dispersion of the error term to be constant. If the model will be available then we know that the error term average should be 0 and the average squared deviation of each error term value with the average should be constant. To see if the error term has constant dispersion it means that the error term is not defined or about a trend among the remaining factors and the dependent variable.

\begin{tabular}{|c|c|c|c|c|}
\hline $\begin{array}{l}\text { F-statistic } \\
\text { ObsR-squared }\end{array}$ & $\begin{array}{l}0.350895 \\
3.793227\end{array}$ & $\begin{array}{l}\text { Probability } \\
\text { Probability }\end{array}$ & & $\begin{array}{l}0.878397 \\
0.704634\end{array}$ \\
\hline \multicolumn{5}{|c|}{$\begin{array}{l}\text { Test Equation: } \\
\text { Dependent Variable: RESID^2 } \\
\text { Method: Least Squares } \\
\text { Date: } 31 / 10 / 16 \text { Time: } 03: 26 \\
\text { Sample: } 111 \\
\text { Included observations: } 11\end{array}$} \\
\hline Variable & Coefficient & Std. Error & t-Statistic & Prob. \\
\hline $\begin{array}{l}\mathrm{C} \\
\text { GDP } \\
\text { GDP^2 } \\
\text { INTKREDIVE } \\
\text { INTKREDIVE^2 } \\
\text { KURSI } \\
\text { KURSI^2 } \\
\end{array}$ & $\begin{array}{l}416.8761 \\
2.900946 \\
-0.187669 \\
-6.759320 \\
0.229196 \\
-6.001805 \\
0.023829 \\
\end{array}$ & $\begin{array}{l}686.9843 \\
3.080352 \\
0.272387 \\
20.91214 \\
0.859460 \\
11.56754 \\
0.044264 \\
\end{array}$ & $\begin{array}{l}0.606820 \\
0.941758 \\
-0.688981 \\
-0.323225 \\
0.266674 \\
-0.518849 \\
0.538347 \\
\end{array}$ & $\begin{array}{l}0.5767 \\
0.3996 \\
0.5287 \\
0.7627 \\
0.8029 \\
0.6312 \\
0.6189 \\
\end{array}$ \\
\hline $\begin{array}{l}\text { R-squared } \\
\text { Adjusted R-squared } \\
\text { S.E. of regression } \\
\text { Sum squared resid } \\
\text { Log likelihood } \\
\text { Durbin-Watson stat }\end{array}$ & $\begin{array}{l}0.344839 \\
-0.637903 \\
1.548115 \\
9.586644 \\
-14.85194\end{array}$ & $\begin{array}{l}\text { Mean dependent var } \\
\text { S.D. dependent var } \\
\text { Akaike info criterion } \\
\text { Schwarz criterion } \\
\text { F-statistic } \\
\text { Prob(F-statistic) }\end{array}$ & & $\begin{array}{l}0.910956 \\
1.209649 \\
3.973080 \\
4.226286 \\
0.350895 \\
0.878397\end{array}$ \\
\hline
\end{tabular}

Since the prob $=0.704634>0.05$ then the basic hypothesis about the lack of heterosit is not rejected. We know that White's test has Hi- Squared distribution $=11^{\star} 0.344=3.784$ We see that the actual value is less than critical, which means that the basic hypothesis is not rejected, then in the model does not exist heteros.

From the assessment of test Heteroskedasticity we see that probability is 0.704634 , and is greater than 0.05 , so Ho is accepted. So we have not heteroskedasticity. We see how the model in general through the Fisher criterion results to us insignificant, since the probability of the actual value is very high $0.878397<0.05$, what means that the first hypothesis stands. Since the model is not significant, this means that the error term which in this case is presented to us as dependent variable is not depending from these factors, they are not connected between them.

So we have not heteroskedasticitet, and the model is unimportant

\section{Testi Reset:}

\begin{tabular}{|c|c|c|c|}
\hline F-statistic & 2.073136 & Probability & 0.193095 \\
\hline Log likelihood ratio & 2.853486 & Probability & 0.091176 \\
\hline
\end{tabular}

Test Equation:

Dependent Variable: INTERES

Method: Least Squares

Date: 31/10/16 Time: 03:30

Sample: 111

Included observations: 11

\begin{tabular}{|c|c|c|c|c|}
\hline Variable & Coefficient & Std. Error & t-Statistic & Prob. \\
\hline GDP & -5.317835 & 2.989461 & -1.778861 & 0.1185 \\
\hline INTKREDIVE & 9.968754 & 5.514612 & 1.807698 & 0.1136 \\
\hline KURSI & -0.560935 & 0.327603 & -1.712240 & 0.1306 \\
\hline FITTED^2 & -0.218514 & 0.151763 & -1.439839 & 0.1931 \\
\hline R-squared & 0.749455 & \multicolumn{2}{|c|}{ Mean dependent var } & 9.081818 \\
\hline Adjusted R-squared & 0.642078 & \multicolumn{2}{|c|}{ S.D. dependent var } & 1.756598 \\
\hline S.E. of regression & 1.050912 & \multicolumn{2}{|c|}{ Akaike info criterion } & 3.212481 \\
\hline Sum squared resid & 7.730912 & \multicolumn{2}{|c|}{ Schwarz criterion } & 3.357170 \\
\hline Log likelihood & -13.66865 & \multicolumn{2}{|l|}{ F-statistic } & 6.979693 \\
\hline Durbin-Watson stat & 1.658594 & \multicolumn{2}{|c|}{ Prob(F-statistic) } & 0.016440 \\
\hline
\end{tabular}

HO: Hub is not important.

$\mathrm{H} 1 \mathrm{Hub}$ is important.

It is shown that: Ffact $\angle$ Fcritic so $\mathrm{HO}$ stands

RESET test says more factorial linear model is a good specified model. So it is not necessary to enter new variables in the model, we have a good model. 